UDC 378.016:81'243

DOI: https://doi.org/10.32820/2074-8922-2021-71-55-62

\title{
USING THE JIGSAW METHOD IN THE ELT AND ESP CLASSROOM AS A WAY TO IMPROVE PROFESSIONALLY RELEVANT SKILLS OF STUDENTS SPECIALISING IN "VOCATIONAL EDUCATION (MANAGEMENT OF THE SERVICE INDUSTRY)”
}

(C) Korniush H.V., Kurbel Yu.O.

Ukrainian Engineering Pedagogics Academy

Information about the Authors:

Hanna Korniush: ORCID: 0000-0003-0829-6742; annakorniush@ukr.net; Candidate of Pedagogical Sciences (Ph.D. in Pedagogical Sciences), Associate Professor of the Department of Foreign Language Training, European Integration and International Cooperation, Ukrainian Engineering Pedagogics Academy, 16 Universytetska st., Kharkiv, 61003, Ukraine.

Yuliia Kurbel: ORCID: 0000-0002-9139-8936; yuliya.kurbel@ukr.net; $3^{\text {rd }}$-year student of the Department of Economics and Management, Ukrainian Engineering Pedagogics Academy, 16 Universytetska st., Kharkiv, 61003, Ukraine.

The present article deals with the phenomenon of the jigsaw method and its benefits for learning a foreign language. Particular attention is placed on the importance of group activities in learning a foreign language and the idea of gamification of the educational process. The paper sheds light on the definition, history and essence of the jigsaw method as a technique which originally helped transform a previously hostile and racially biased learning ambience into a supportive collaborative learning environment where each student was engaged and acted as an important constituent of the group.

The experience of employing this method in the ELT and ESP courses with the $2^{\text {nd }}$ and $3^{\text {rd }}$ year students specialising in management of the service industry within the 2019/2020 and 2020/2021 academic years allows stating that the potential of the jigsaw method is so enormous that it can enrich the ELT and ESP classroom helping students not only develop their language skills (listening, reading, speaking and writing) and actively practise topical vocabulary but also acquire a range of crucial $21^{\text {st }}$ century skills, namely soft skills.

Special emphasis is put on the ways to use the jigsaw method in the process of teaching English at different levels of education. The paper provides practical recommendations on how to incorporate the jigsaw method in the ELT and ESP courses to receive the maximum result, defines the basic principles of implementing the jigsaw method and dwells upon the challenges which might occur when applying the method. The authors also highlight that the jigsaw method can be mixed with the case-study and business game methods. The conducted research proves that the jigsaw method is really effective within the ESP and Business English courses aimed at students majoring in "Vocational Education (Management of the Service Industry)" since it equips them with the necessary language skills and soft skills which contribute to the overall development of students as qualified specialists possessing a range of professionally relevant competences and competencies.

The article finishes with a few suggestions concerning prospects for further scientific research in the field of practical verification of the effectiveness of incorporating the jigsaw method in the ESP, ELT and Business English offline, online and blended learning environment at higher education institutions.

Keywords: jigsaw method, jigsaw technique, ELT, ESP, cooperative learning, professional competences, soft skills.

Корнюш Г.В., Курбель Ю.О. «Використання методу групового пазлу на заняттях з англійської мови з метою розвитку професійно значущих навичок студентів спеціальності «Професійна освіта (Сфера обслуговування)».

У даній статті розглядається метод «груповий пазл» (“jigsaw method”) та його переваги у процесі навчання іноземної мови. Особлива увага приділяється важливості групової діяльності у вивченні іноземних мов. Стаття проливає світло на визначення, історію та суть методу «груповий пазл» як техніки, яка допомогла перетворити раніше ворожу та упереджену навчальну атмосферу у сприятливе середовище інтерактивного навчання, де кожен студент почувається активно залученим i являє собою невід’ємну складову групи та проєкту. 
Досвід використання методу «груповий пазл» на заняттях у межах дисциплін «Іноземна мова (англійська)» та «Іноземна мова професійно-ділового спілкування (англійська)» для студентів 2-го та 3-го курсів спеціальності 015 «Професійна освіта (Сфера обслуговування)» протягом 2019/2020 та 2020/2021 навчальних років дозволяє стверджувати, що потенціал цього методу настільки значний, що сприяє не тільки розвиткові мовних навичок (аудіювання, читання, говоріння, письма) та активному використанню професійно релевантної лексики, але й набуттю низки важливих навичок XIX століття (зокрема - м'яких навичок).

У роботі містяться практичні рекомендації щодо того, як інкорпорувати названий метод на заняттях 3 іноземної мови для отримання максимального результату, визначено основні принципи впровадження методу «груповий пазл» та виокремлено складнощі, які можуть виникнути під час застосування цього методу. Авторами наголошується, що метод «груповий пазл» можна дієво поєднувати 3 кейс-методом та діловими іграми. Проведене дослідження доводить, що метод «груповий пазл» $\epsilon$ дійсно ефективним у межах курсів «Іноземна мова професійно-ділового спілкування (англійська)» та «Ділова мова (англійська)», які викладаються студентам, що здобувають спеціальність 015 «Професійна освіта (Сфера обслуговування)», оскільки озброює їх необхідними мовними та м'якими навичками, а також сприяє загальному становленню студентів як кваліфікованих фахівців, що володіють цілим рядом професійно значущих компетенцій.

Ключові слова: груповий пазл, метод, навчання, англійська мова, професійні компетенції, м'які навички.

Introduction. Nowadays teaching methodology is becoming more and more diverse and interactive. Student-centeredness is believed to be the key priority in education along with the trends of interactivity, gamification and blended learning. New teaching tools and strategies are being invented to make classes more interesting and enjoyable. This is particularly true about organising ELT (English Language Teaching) and ESP (English for Special Purposes) classes.

Classes are now structured in such a way that the group is fully involved. The teacher is expected to communicate with everyone. Learning a language in such an engaging and cooperative environment allows group members to interact with each other, communicate, share experiences. Therefore, game methods in the educational curriculum are gaining popularity. This is due not only to the need to activate educational and cognitive skills of students, but also to develop their attentiveness, concentration, ability to search and analyse the information received.

The concept of the "game" and "gamification" of the educational process in the 21 st century is interpreted in different ways. In most cases, the game is no longer perceived as an entertainment and leisure activity. The game has evolved into a way of teaching, upbringing, development, adaptation, etc. Now in the field of education, gaming technologies have received such a strong development that they are considered to be a separate method of organising and conducting classes [6].

One of the types of organising group classes is the jigsaw method, in which all the students depend on each other. The main idea is that the teacher divides the group into micro groups (4-6 people) or pairs, and divides the tasks into parts that the students must put together like a puzzle. The method fosters the development of soft skills, language skills and professionally relevant qualities of students whose future jobs are going to involve a significant communication or managerial component.

We recognise that there exists a strong correlation between what and how learners study and how successful they become in their future careers. Using such a method can bridge the gap between the ELT and ESP classroom and the workplace. Taking into consideration the fact that sometimes there is a mismatch between the content of ESP textbooks and the actual demands from employers [2], teachers need to know what they can complement textbooks with and how they can create situations for students to practice different language skills and further develop their people skills.

So, the present article focuses on how the jigsaw method can be used in the ELT and ESP classroom with the purpose of improving professionally relevant competences of students majoring in "Vocational education (Management of the service industry)".

Analysis of recent research works and publications. While conducting the current research, it was important to study previously published works dealing with the issue of the jigsaw method and its effectiveness in the process of English language teaching. The literature review helped see that valuable works belong to Elliot Aronson, Filkins Champaign, Kai 
Hakkarainen, Spencer Kagan, Gareth Rees, Scott Baan Jafar Sadiq, Siti Mina Tamah et al. However, it was found out that the jigsaw method had never been explored in terms of teaching ESP courses to students specialising in vocational education and/or management, which was why the current research was undertaken.

It should be mentioned that numerous works related to the history and methodology of using the jigsaw method in education (without any specific focus on foreign language teaching) were also taken into account because they served as sources of background information shedding light on why and how the method evolved and can be applied in the teaching and learning process.

Methods. To carry out the research we have used a variety of different theoretical and empirical methods. First, to situate our research in the existing body of work, and to evaluate trends within the research topic, a literature review was done. An analysis of curricula and syllabuses was conducted to study the learning outcomes of the specialised disciplines taught to students of the specialty 015 "Vocational education (Management of the service industry)" at Ukrainian Engineering Pedagogics Academy (Kharkiv, Ukraine). The analysis helped us understand whether and how our hypothesis about the effectiveness of implementing the jigsaw method within the ELT and, particularly, ESP courses aimed at future managers for the service industry can be tested and proved. After that, a series of surveys was conducted, which made it possible to reveal the language barriers that future managers for the service industry experienced and the expectations that they had from the English courses taught at Ukrainian Engineering Pedagogics Academy. Then, the jigsaw method was introduced as an experiment in groups of the $2^{\text {nd }}$ and $3^{\text {rd }}$ year students specialising in "Vocational education (Management of the service industry)" (within the 2019/2020 and 2020/2021 academic years). Activities involving the jigsaw technique fully corresponded to the syllabuses and topics of the disciplines "Foreign Language (English)" and "Foreign language of professional and business communication (English)". What is more, they were introduced regularly and never took more than 40 minutes of the academic time. Each semester students were offered language tests and surveys, both of which gave a clear understanding of how their positive attitude to the course shaped and how much their performance improved along with the array of soft skills.

The aim of the research was to study the essence of the jigsaw method in general and the ways of using it in the ELT and ESP classroom as a way to improve professionally relevant competences of future VET teachers specialising in management and managers for the service industry.

Results \& Discussion. First, we consider it important to dwell upon the essence of the jigsaw method. Jigsaw is a specific type of group learning experience wherein each student must cooperate with their peers to achieve their common and individual goals. This is what the name for the method stems from: students are organised like pieces in a jigsaw to form different kind of groups, where each student (a piece) must be part of the solution to the jigsaw puzzle.

The jigsaw classroom is a research-based cooperative learning technique invented and developed in the early 1970 s by social psychologist Elliot Aronson and his students at the University of Texas and the University of California. Since 1971, thousands of classrooms have used jigsaw with great success [1]. The description of this method is as follows: the material is divided into separate puzzles, which are assembled together piece by piece into one overall picture. The teacher's task may vary depending on the goals and objectives set within the class. Students can assemble the final picture themselves, guess the coded answer or compose a story, build a logical chain, explain why the details of the picture were formed in this or that order, etc.

Historically, the jigsaw method was designed to promote empathy, compassion, and sense of belonging. Obviously, when it made its appearance, it was aimed to fight against racial prejudices which elementary school students had or experienced. Back then, in the early 1970s, when there was an urgent need to diffuse tension in classrooms which included black, Hispanic, and white students. Elliot Aronson figured out that the learning environment was quite competitive and biased. Therefore, he put forward a suggestion that a cooperative environment should be developed where students could rely on each other to gain necessary knowledge and skills.

After the method was implemented, children, previously hostile to one another, appeared to be much more supportive and encouraging. They helped each other progress since the success of every individual student depended on how well all the others worked and interacted. Introducing the jigsaw method, where each student acted as a piece essential for the production and full understanding of the final product, helped soften racial tensions, promoted engagement, interaction, developed group-work skills (as well as a number of other soft 
skills) and helped students acquire the assigned materials better.

The idea is that students are provided with the opportunity to become "experts" on a particular subject, and share that knowledge with their peers. This technique promotes both self- and peerteaching, which requires students to understand the material at a deeper level and engage in discussions, problem solving, and other educational activities. The jigsaw strategy is used to develop the skills and expertise needed to participate effectively in group activities. It focuses on listening, speaking, cooperation, reflection and problem-solving skills. Obviously, the jigsaw method is an absolutely effective tool aimed at helping students integrate knowledge and understanding from various sources and experts [3].

Jigsaw is a multifunctional structure of cooperative learning which can be used in a number of ways for a variety of goals, but it is primarily used for the acquisition and presentation of new material, review, or informed debate. The use of this group-work activity creates interdependence and status equalisation. The basic idea, as explained above, is very simple: students are divided into groups which all have their own research topic to study. After doing research, each topic group is split in such a manner that new groups have a single member from each of the old topic groups. After the new groups have been assembled, each topic expert is responsible for integrating the knowledge of their topic-specific knowledge into the understanding of the new group they are in. Each student on the team becomes an "expert" on one topic by working with members from the other teams assigned the corresponding expert topic. Upon returning to their teams, each one in turn teaches the group; and students are all assessed on all aspects of the topic.

After a given time, the original groups are disbanded and new ones are formed, which unite "experts" on each aspect of the problem. At this stage, an exchange of opinions of experts takes place, as a result of which their understanding of the issue deepens, and the questions that arose at the first stage of studying the problem are eliminated. As a result of work in this phase, "experts" must assimilate the educational material at a level that would allow them to consciously and accurately convey the content of this educational material to the other students who are not initiated into this particular aspect of the issue.

In the third step, the "experts" return to their original groups and transfer the acquired knowledge to the other members of the group (who are not familiar with this aspect of the problem, but are "experts" on another aspect). At this stage, students learn to listen carefully to their peers, independently explain new material, ask questions and answer them.

At the final stage, the teacher checks the level of assimilation of all aspects of the problem by each member of the group. Control can take place in any known form and ensures the integrity of the work of the "experts".

The basic principles of implementing the jigsaw method include:

- the principle "from more to less": before putting together a large puzzle, it is always necessary to think over the decomposition of the central concept which can be obtained as a result of collecting the entire puzzle;

- the principle of "unity and consistency": the jigsaw method is best used when working in small groups; when applying this method in big groups, the most active students will be engaged in puzzle collection. It is going to be difficult for the teacher to constantly monitor and moderate the group work ensuring that every single student should be involved. In addition, if a large puzzle is made, students may not perceive all the information and lose the logic of collecting individual components;

- the principle of "integrity": the jigsaw method is convenient for transmitting a small amount of information. Therefore, it is necessary to take into account that a large number of details, the loss of the logic of the relationship between the details and unnecessary data can overload the final picture. Simplicity, relevance, brevity are the main prerequisites for the success of any jigsaw activity.

The jigsaw method involves communication and interaction, serves to promote group-work and other people skills. The method can benefit the educational process at both secondary education institutions and higher education institutions. Any group projects can be carried out using this technique. Moreover, it can be used when teaching different disciplines, with the ELT and ESP classrooms being a perfect field for implementing this method. It should be mentioned that any successful jigsaw activity necessitates reasonable timing, time-management and monitoring.

Teaching English as a foreign language is about having a dialogue which aims to be educational. The nature of the jigsaw method absolutely corresponds to the nature of the process of teaching English because learners get fully engaged in interactive communication which 
makes it possible to exchange information and learn from each other. By means of speaking and active listening, students develop their language skills and improve their soft skills - all this constitutes the basis for mastering English in a communicative and cooperative way.

The jigsaw method has proved to be effective while teaching reading, listening, writing and speaking. For example, information gap exercises can be used as jigsaw reading and listening activities. Learners can be divided into groups and asked to carefully read or listen to different parts of the texts. After that they join other groups that have not read or heard their abstracts and have to share the information so that the others get a complete picture. Obviously, this is a golden opportunity to integrate different skills because students listen to the teacher or native speakers (audio-materials) as well as to one another, read texts, speak to each other to share the information they have received. While listening and reading, students can also be encouraged to take notes or present the results of the jigsaw activity in the written form in order to integrate writing as well.

Reading activities, where students read different parts of the text and then join their groups to give them the overview of it, are managed more easily in comparison to listening activities. Managing a jigsaw listening activity is much more challenging since the teacher needs to prepare several tape recorders and create enough space for listening without disturbing groups which listen to different extracts. The issue can be solved if students have individual headsets or headphones which will enable them to listen to abstracts without disturbing anyone around.

According to Gareth Rees [4], jigsaw reading activities can be carried out in two ways. We believe that listening can also be taught using these activities.

First, the teacher selects a story (a video clip or an audio track) for students to read (listen to) and divides it into two parts. Then the students are split into two groups. One group (group A) studies the first part of the text (listening material) and the other group (group B) studies the second fragment correspondingly. After the students have read (listened to) their text fragments, they pair up with someone from the other group and reconstruct the full story together. The teacher should monitor the students' work, making sure that the learners do not change into their native language to facilitate the retelling. It is also important to make sure that those students who have studied the first part of the text (audio) start retelling the story first.

Second, the teacher takes two stories which share the same topic. Students are then divided into two groups which receive different stories and study them (answer questions, discuss them, etc). After, each student is paired up with someone from the other group and is asked to retell the story to his/her partner. The partner then answers the questions about the text that his/her peer has just shared. This is how the teacher can understand the quality of the texts comprehension.

The content of the reading and listening materials should depend on the students' level and the topic which is currently studied within the ELT or ESP course. Jigsaw activities may involve reading professional texts, studying audio and video materials which deal with job-related questions. Within the ESP course or Business English course the jigsaw method can be mixed with the case-study and business game method.

Taking into account that students specialising in vocational education study a number of socio-pedagogical disciplines and those ones majoring in management of the service industry study specialised disciplines such as management, operational management, economic theory, economics, accounting, business activities, etc., they need to be able to use the knowledge in international contexts, which means being capable of using English at a sufficient level in everyday and professional situations. What is more, cooperative activities can greatly influence students' communication skills which are regarded as a must for both future teachers and managers. The ESP course which involves case-study and business game methods proves to be much more effective and engaging due to its interdisciplinary nature and active use of close-to-life situations.

For example, during classes in management, students often face situational tasks or the case method. The case method is a teaching technique that uses a description of real economic, social and business situations. Students should investigate the situation, understand the essence of the problem, suggest possible solutions and choose the best one. Cases are based on real factual material or are close to a real situation. ESP classes can use professionally relevant cases for students to discuss and find a good solution to. It helps focus on topical English vocabulary, develop communication skills. However, the case method can also be enriched with the jigsaw method. Cases can be presented as reading or listening material for a small group of students who will have to share 
the case with the others who have not read or listened to it. Such an activity will help students become more responsible and careful while reading or listening because their peers depend on how well they understand the case and how clearly they can relate it. Topical vocabulary will be actively used in both speaking and listening.

The business game method is also often used at lectures on business activities [5]. Business games are designed to provide an effective learning experience for managers who wish to develop their strategic decision-making skill. They can be carried out through role plays, exercises and simulations. When the jigsaw method is used to deliver a situation for a business game or a task of exchanging information is organised as a jigsaw activity, the learning environment becomes more enriched with interactivity and collaboration.

As we see, future VET teachers and managers (for the service industry in particular) can benefit much from the jigsaw method because English is practiced in so many different engaging ways.

It has already been mentioned in the paper that the jigsaw method improves not only language skills but also a number of other skills. The jigsaw method is very important for future managers and VET teachers of management because they need to communicate with people, solve problem as soon as possible, be creative, and know a foreign language to easily communicate with international partners, grow professionally and take part in international business or educational projects. It is highly important for a manager to:

- be assiduous and attentive as the profession requires strenuous work, most often related to paperwork and calculations;

- have an analytical mind and scrupulous mathematical and logical thinking, love to work with numbers; situation;

- know how to quickly concentrate in any

- be emotionally stable, because managerial (and sometimes teaching) activities are often associated with stress, urgent preparation of reports, analysis of large amounts of information in a short time;

- be principled, honest and responsible.

Evidently, soft skills are an important element of a professional portrait and reputation in the modern world. Soft skills are personal skills that help negotiate with people, achieve success in work and life. These include time management, poise, motivation, teamwork, responsibility, etc. Such qualities are difficult to track and demonstrate. But they are the future of many professions. To expand future managers' and management teachers' opportunities in the profession, it is crucial for every young specialist to develop four different groups of soft skills related to:

- communication (skills which help successfully interact with people);

- self-development (skills that are responsible for further professional development in the chosen field);

- determination (skills which allow achieving success and overcoming obstacles on the way to the goal;

- leadership (skills that are needed to lead people, motivate and correctly allocate resources to achieve goals).

The paradox of soft skills is that they are intangible, but they strongly affect the success at work.

Before introducing the jigsaw method into the education process, it is necessary to understand what a vocational teacher and a service management professional should know, what skills are important for them to develop and if the potential of foreign language learning can benefit the development of professionally relevant qualities and skills. It was found out that future service sector managers and would-be VET teachers majoring in management study a number of interdependent specialised subjects such as Management, Social and Corporate Security, Management Solutions, Economics, Business Organisation, Logistics, Service Marketing, Controlling, Enterprise Economics as well as a wide range of pedagogical and psychological disciplines.

After studying carefully the learning outcomes for the Bachelor's curriculum for "Vocational Education (Management of the Service Industry)" (at Ukrainian Engineering Pedagogics Academy), it became evident that a professional in management for the service industry (as well as a VET teacher) should develop a range of important hard skills. However, the curriculum also includes a vast array of soft skills. For instance, when studying Management, students are expected to acquire learn management methods used in management practice; theoretical and practical aspects of staff motivation; elements and stages of the communication process; the main provisions of the theory of leadership and leadership; causes of conflicts and approaches to overcoming them; system of indicators of economic, organisational and social efficiency of management, their composition and methods of 
determination, etc. After learning such a discipline as Management Solutions, students are supposed to know the essence of management solutions; the content of management solutions; decision-making management procedures; formal and informal decision-making methods, etc. After studying such a discipline as Business Organisation, students get to know psychological and ethical aspects of entrepreneurial activity, forms of interaction and cooperation of business entities, etc.

Evidently, the learning outcomes listed above prove that the knowledge and hard skills that future managers for the service industry and VET teachers in this field are expected to acquire are directly related to personal and interpersonal soft skills, namely communication skills, leadership, problem-solving, flexibility, analytical thinking, creative thinking, decision-making, ability to learn, creativity, result-orientation, perseverance, resistance to stress, team-work skills, ability to resolve conflicts, etc.

Although the English language is not a specialised discipline, it can be a great addition to the educational process aimed at building hard and soft skills of would-be managers or management teachers in case English courses taught at higher education institutions have relevant modern content and interactive organisational form. As a result of the conducted research, the jigsaw method was found to be beneficial for both hard and soft skills development. The experience of employing this method in the ELT and ESP courses with the $2^{\text {nd }}$ and $3^{\text {rd }}$ year students specialising in management of the service industry within the 2019/2020 and 2020/2021 academic years allows saying that this method has much complemented the content of the specialised disciplines of the managerial and pedagogical cycle. One of the successes of the method was the fact that is helped improve engagement, involvement as students turned out to be more engrossed in the process of reading and speaking, listening and writing. They learnt to be more attentive to each other and more patient. The jigsaw method created a supportive and cooperative learning environment in which students worked together to accomplish the same goal instead of working against each other. They

\section{References:}

1. Aronson E. The Jigsaw classroom [Electronic resource] / E. Aronson // The Jigsaw classroom : website. - Access mode : http://www.jigsaw.org. (Last accessed : 22.12.2020).

2. Bouzidi H. Language attitudes and aptitudes \& their implications for education / H. Bouzidi. - Chisinau : LAP Lambert Academic Publishing, 2015. - 228 p. learnt to communicate with different people who constituted their group, learnt to listen to each other, bore responsibility for the common project, felt engaged and experienced the necessary sense of belonging.

The jigsaw method helped students develop the above-mentioned skills and, as a result, become more valuable as professionals directly influencing their employability. In the questionnaire, $88 \%$ of students noted that the jigsaw technique helped them improve their managerial and teaching skills, soft skills and, certainly, it influenced the way they used and perceived English. Using the language to deliver information that everybody in their group waited for, students realised the importance of speaking clearly and accurately. English was perceived by them as a means of communicating important information, as a way to collaborate and achieve a common result.

Conclusions. Using different forms of work in the ELT or ESP classroom is bound to foster the development of language skills and professionally relevant hard and soft skills. For a more effective result, teachers should employ different instructional tools and methods in the classroom, mix and experiment with them. Classical teaching, involving translations and methodical work with textbooks, is outdated and boring. Therefore, new teaching techniques aimed at simulating real-life situations should be introduced. The jigsaw method is one of such techniques in which learning is organised in a cooperative, authentic and engaging way. Future VET teachers and managers for the service industry, as well as other specialists whose professional activity involves much communication, negotiation and problem-solving, are likely to improve not only the core language skills but also a number of soft skills necessary to succeed on the demanding and competitive job market.

Further research into the issue should deal with studying the most effective ways of implementing the jigsaw method in mixed-ability groups since having students whose language level is different may complicate the process of organising jigsaw activities within the ELT and ESP courses.

3. Hakkarainen K. Jigsaw [Electronic resource] / K. Hakkarainen // Aalto Media Lab : website. Access mode : http://mlab.taik.fi/polut/Yhteisollinen /tyokalu_jigsaw.html. - (Last accessed : 22.12.2020)

4. Rees G. Jigsaw reading. [Electronic resource] / G. Rees // British Council : website. - Access mode : https://www.teachingenglish.org.uk/article/jigsawreading. - (Last accessed : 12.12.2020) 
5. Злобин С. Метод и базовые модели деловой игры / С. Злобин, И. Соловьев // Cloud of science : сб. науч. тр. - 2018. - Вып. 5 (4). - С. 608-619.

6. Потапова А. Методические особенности реализации метода «Пазлы» в учебном процессе [Электронный ресурс] / А. Потапова // Современная педагогика. - 2016. - № 6. - Режим доступа : http://pedagogika.snauka.ru/2016/06/5773. - (Дата обращения : 12.12.2020)

\section{References (transliterated and translated):}

1. Aronson, E n.d., 'The Jigsaw classroom', The Jigsaw Classroom, viewed 22 December 2020, $<\mathrm{http}$ ://www.jigsaw.org $>$.

2. Bouzidi, H 2015, Language attitudes and aptitudes \& their implications for education, Lambert Academic Publishing, Chisinau.
3. Hakkarainen, K n.d., 'Jigsaw', Aalto Media Lab, viewed 22 December 2020, <http://mlab.taik.fi/ polut/Yhteisollinen/tyokalu_jigsaw.html $>$.

4. Rees, G 2016, 'Jigsaw reading', British Council, viewed 12 December 2020, $<$ https:/www.teachingenglish.org.uk/article/jigsawreading $>$.

5. Zlobin, S \& Solovyov, I 2018, 'Metod i bazovye modeli delovoy igry' [Method and basic models of the business game], Cloud of science, iss. 5 (4), pp. 608-619.

6. Potapova, A 2016, Metodicheskie osobennosti realizatsii metoda Pazly $\mathrm{V}$ uchebnom protsesse [Methodology implementation method "Puzzles" in educational process], Sovremennaya pedagogika, no. 6, viewed 12 December 2020, $<$ http://pedagogika.snauka.ru/2016/06/5773>.

The article was received 02 May 2021 